\title{
The Influence of People's Knowledge and Attitudes Toward Traditional Treatment
}

\author{
Marniati \\ Faculty of Public Health University of Teuku Umar, Indonesia \\ marniati_skm@yahoo.co.id
}

\begin{abstract}
Traditional medicine is the treatment by means of drugs and treatment which refers to the experience and skills from generation to generation and it is applied in accordance with the norms prevailing in society. The purpose of this research is to analyze the influence of people's knowledge and attitudes toward a traditional treatment to victims of traffic accidents. This research is an analytical Survey with Crosssectional approach. Research samples (total population) comprised 47 people. Data were analyzed by univariate and Bivariate (kai Squares). From the data obtained that the people who suffered a traffic accident were 25 people $(27.8 \%)$. The results showed a significant influence of factors of knowledge and attitude of the people and traditional treatment for traffic accident victims, where the results ware ( $P$ Value $<\boldsymbol{\alpha}=0.05$ ). There is a significant relationship between people's knowledge and attitudes and traditional treatment to victims of traffic accidents in the district of Nagan Raya, Seunagan Year 2015. It is expected that the public can choose the appropriate traditional treatment in order to get a good healing and has no side effects.
\end{abstract}

Keywords - Knowledge, attitudes, and traditional treatment

\section{INTRODUCTION}

Traffic accidents, according to WHO (2014) in the BIN (2014) states that in the past two years in 2013 and 2014, traffic accidents in Indonesia by the World Health Organization (WHO) considered being the biggest third killer, under coronary heart disease and tuberculosis (TBC). Data of WHO in 2011 says that 67 percents of victims of traffic accidents are in the productive age, i.e 22-50 years. There are about 400,000 victims under the age of 25 years who died on the highway, with an average mortality rate of 1,000 children and adolescents every day. In fact, traffic accidents are the main cause of death of children in the world, with an age range 10-24 years.

Data from the Central Bureau of Statistics (2012) the number of victims of traffic accidents in 2007 was 49.553 inhabitants and increased in 2010 which is accident victims became 66.488 people, with a death toll was as many as 19873 people, victims with seriously injured was as many as 26.196 people, and victims with light injured was as much as 63809 in habitants [3]. Based on these data, there are 54 people who died in traffic accidents every day, or in other words, every 26 minutes there is one person died [4].

Based on data from the Directorate General of Land Transportation, the incidence of traffic accidents in Indonesia continues to increase from year to year. In 2009, the number of accidents reached 109.319 cases in 2010 and 105.009 in 2011 with a number of 128.999 cases [5]. In 2012 with a number of 146.462 cases, in 2013 were as many as 169396 cases and in 2014 had 165.32 cases [5].

The total number of road accidents in the Aceh province is still quite high [6]. From the data released by Dishub komintel Aceh in the last three years, as many as 2,104 people died from road accidents. The number of traffic accidents in 2010 reached a total of 806 cases when 649 people died [7]. It increased in 2011 with a total number of 1,327 cases (up 64.64\%), 732 people died (up $12.7 \%$ ). While in the year 2012, from 1,413 cases (up 6.48\%) 723 people (down 1.2\%) died [8].

In Nagan Raya, throughout 2014 traffic accident cases, there was an increasing number compared to the previous year, based on medical records of Health Office (DHO) Nagan Raya in 2014, there were 709 cases of traffic accidents, where the number of accident victims was 457 males and 242 females [9].

Based on the medical records of health center of Prom, a number of traffic accidents patients in 2014 from January to December were as many as 90 people in which there were 25 people $(27.8 \%)$ who experienced fractures and $65(72.2 \%)$ injured $^{10}$. People who suffered a traffic accident then chose a treatment with a variety of alternatives, there were 41 people $(45.5 \%)$ who choose medical treatment for the treatment of accidents (and as many as 49 
people $(55.5 \%)$ prefer traditional treatments such as going to the traditional healer or physician [11]. The number of people who choose traditional treatment is more than the number of people who choose medical treatment, this because they more believe will get a quickly healing even without surgery and it does not take a long time for healing, while medical treatment force them to have surgery for installing iron pan if there are any fractures [12].

Based on the preliminary interview with 10 people who had accident, it is found that as much as five people $(50 \%)$ who chose the traditional treatment for fear of being part of an accident be cut or amputated if they chose medical treatment in the hospital, 3 others $(30 \%)$ said that they decided to have traditional medicine because it does not have side effects and using traditional medicines such as leaves are easily obtained and 2 others (20\%) prefer traditional medicine for a quick recovery without any surgery and also easier treatment.

\section{METHOD}

This research is a kind of analytical survey with cross sectional approach. The total population is about 90 people who got accidents in the village of Blang Puuk Nigan Seunagan, Nagan Raya district in 2014, the sample is random sampling. The method of sample selection is any people who have had an accident or do not, and it is obtained the number of samples is 47 people.

\section{RESULT}

Blang Puuk Nigan Seunagan is a village that has population of 344 people consists of 159 males and 155 females for the inhabitants. Blang Puuk Nigan society owns several occupations and profession such as agricultural activities, employees, farmers, plantation, and some of them may do any other jobs to make living. Natural resources which are the most dominant in Blang Puuk Nigan is agricultural land and plantation reaching 12.5 hectares, including fully utilized land or not.
A. Age

TABLE I.

FREQUENCY DISTRIBUTION OF RESPONDENTS BY AGE RESPONDENTS IN BLANG PUUK NIGAN 2015

\begin{tabular}{|c|c|c|c|}
\hline No. & Age & Frequency & \% \\
\hline 1. & $33-35$ & 16 & 34,1 \\
\hline 2. & $38-39$ & 12 & 25,5 \\
\hline 3. & $40-41$ & 13 & 27,6 \\
\hline 4. & $42-41$ & 6 & 12,8 \\
\hline \multicolumn{2}{|c|}{ Total } & $\mathbf{4 7}$ & $\mathbf{1 0 0}$ \\
\hline
\end{tabular}

B. Knowledge

TABLE II.

FREQUENCY DISTRIBUTION OF RESPONDENTS BY KNOWLEDGE RESPONDENTS AGAINST MEDICAL ACCIDENTS SEARCH IN BLANG PUUK NIGAN 2015

\begin{tabular}{|c|l|c|c|}
\hline No. & Knowledge & Frequency & \% \\
\hline 1. & Good & 10 & 21,3 \\
\hline 2. & Enough & 17 & 36,2 \\
\hline 3. & Less & 20 & 42,6 \\
\hline \multicolumn{2}{|c|}{ Total } & $\mathbf{4 7}$ & $\mathbf{1 0 0}$ \\
\hline
\end{tabular}

\section{Attitude}

TABLE III.

FREQUENCY DISTRIBUTION OF RESPONDENTS BY ATTITUDES OF Respondents Against MEdical ACCIDENTS SEARCh IN BLANG PuUk NIGAN 2015

\begin{tabular}{|c|l|c|c|}
\hline No. & Attitude & Frequency & \% \\
\hline 1. & Positive & 21 & 44,7 \\
\hline 2. & Negative & 26 & 55,3 \\
\hline \multicolumn{2}{|c|}{ Total } & $\mathbf{4 7}$ & $\mathbf{1 0 0}$ \\
\hline
\end{tabular}

D. Search for Traditional Medicine in Accident Victims

TABLE IV.

FREQUENCY DISTRIBUTION OF RESPONDENTS BY SEARCH MEDICAL ACCIDENTS IN BLANG PUUK NIGAN 2015

\begin{tabular}{|c|c|c|c|}
\hline No. & $\begin{array}{c}\text { Search } \\
\text { Treatment }\end{array}$ & Frequency & \% \\
\hline 1. & Yes & 30 & 63,8 \\
\hline 2. & No & 17 & 36,2 \\
\hline \multicolumn{2}{|c|}{ Total } & $\mathbf{4 7}$ & $\mathbf{1 0 0}$ \\
\hline
\end{tabular}

E. Influence of Knowledge Factor to search Medical Accidents

TABLE V.

FACTORS INFLUENCING KNOWLEDGE SEARCH MEDICAL ACCIDENTS IN BLANG PUUK NIGAN 2015

\begin{tabular}{|l|c|c|c|c|c|c|c|}
\hline \multirow{2}{*}{$\begin{array}{c}\text { Knowl } \\
\text { edge }\end{array}$} & \multicolumn{6}{|c|}{ Search Medicine accident } & \multicolumn{2}{|c|}{ Total } & \multirow{2}{*}{$\boldsymbol{P}$} \\
\cline { 2 - 7 } & \multicolumn{2}{|c|}{ Yes } & \multicolumn{2}{|c|}{ No } & \multicolumn{2}{|c|}{} \\
\cline { 2 - 7 } & $\mathbf{f}$ & $\mathbf{\%}$ & $\mathbf{f}$ & $\mathbf{\%}$ & $\mathbf{F}$ & $\mathbf{\%}$ & \\
\hline Good & 3 & 30,0 & 7 & 70,0 & 10 & 100 & \\
\hline Enough & 9 & 52,9 & 8 & 47,1 & 17 & 100 & \multirow{2}{*}{0,002} \\
\hline Less & 18 & 90,0 & 2 & 10,0 & 20 & 100 & \\
\hline Total & $\mathbf{3 0}$ & $\mathbf{6 3 , 8}$ & $\mathbf{1 7}$ & $\mathbf{3 6 , 2}$ & $\mathbf{4 7}$ & $\mathbf{1 0 0}$ & \\
\hline
\end{tabular}


F. Factors Influence Attitudes to search Medical Accidents

TABLE VI.

FACTORS INFLUENCING ATTITUdES SEARCH MEDICAL ACCIDENTS IN BLANG PUUK NIGAN 2015

\begin{tabular}{|c|c|c|c|c|c|c|c|}
\hline \multirow{3}{*}{ Attitude } & \multicolumn{4}{|c|}{$\begin{array}{c}\text { Search Medicine } \\
\text { accident }\end{array}$} & \multirow{2}{*}{\multicolumn{2}{|c|}{ Total }} & \multirow{3}{*}{$\boldsymbol{P}$} \\
\hline & \multicolumn{2}{|c|}{ Yes } & \multicolumn{2}{|c|}{ No } & & & \\
\hline & f & $\%$ & f & $\%$ & f & $\%$ & \\
\hline Positive & 8 & 38,1 & 13 & 61,9 & 21 & 100 & \\
\hline Negative & 22 & 80,6 & 4 & 15,4 & 26 & 100 & 0,003 \\
\hline Total & 30 & 68,1 & 17 & 36,2 & 47 & 100 & \\
\hline
\end{tabular}

IV. DISCUSSION

A. Influence of Knowledge Factor in Finding Accidents Medicinal Treatment

Based on test results of chi square obtained pvalue $=0.002$ and that is smaller than $\alpha=0.05$ (pvalue $=0,002<\alpha=0.05$ ) that can be drawn a significant influence between the factors of knowledge and traditional treatment finding for accident victims at Blang Puuk Nigan Seunagan District of Nagan Raya.

Knowledge is the result of the idea, and this occurred after people perform sensing on a specific object [15]. This sensing occurs through human senses, the senses of sight, hearing, smelling, tasting and touching. Most of the knowledge gained through the eyes and ears ${ }^{14}$. From experience and research proved that behavior which is based on knowledge will be more lasting than the behavior that is not based on knowledge [15].

This research results are in lines with the result conducted by Supriya (2014). Based on data obtained from the field, it can be concluded that the knowledge of traditional treatment has a significant relationship to the community decision-making in choosing traditional medicine because it has pvalue of 0,046 or less than the value $\alpha$, that is 0,05 [16].

Based on the observations of researchers in the field, it can be assumed that people seek traditional treatment at the time of an accident such as going to a physician, because of their prior knowledge about traditional medicine and it is proven recovery [17]. Based on the knowledge factor, there are many people who prefer to do the traditional treatment at the time of the accident than to be treated medically [18]. This is because people are afraid to take some medical treatments which usually offer them to undergo surgery and long recovery time [19].

\section{B. Influence of Attitudes Factor in Finding Accidents Medicinal Treatment}

Based on test results of chi square obtained pvalue $=0.003$ and that is smaller than $\alpha=0.05$ (pvalue $=0,003<\alpha=0.05$ ) that can be concluded that there is a significant influence between the factors of attitudes and traditional treatment finding for accident victims at Blang Puuk Nigan Seunagan District of Nagan Raya.

Attitude is a feeling of readiness to react to an object in a certain way, the form of positive and negative reactions with attitude includes the likes and dislikes, to approach and to avoid situations, objects, people, groups, and social policy [20] Result of this research is in accordance to a research conducted in which the influence of the attitude of the people in choosing traditional treatment for every disease, such as bone fractures accident [21].

Based on the observations of researchers in the field, the researchers assume that people seek traditional treatment at the time of an accident such as going to a physician, because the attitude of people, who prefer the nearest treatment such as traditional medicine, compared to going to the hospital and stay overnight in the hospital ${ }^{22}$. Surrounding communities have an attitude or a positive view of traditional medicine, it is because people assume that traditional medicine has no side effects and the recovery process does not take long time [23].

Based on the research results and observations that have already done entirely by the researcher in the field entirely, it is found that traditional medicine for the accident victim has its own weaknesses; i.e drugs are used or provided is not hygienic enough such as the nutmeg is crushed in a same container that is used to grind other herb [24]. Besides traditional treatment is done with nonsterile circumstances, for example the physician who did not wash his hands after the treatment one patient, he direcly holds other patient [25]. It is extremely dangerous to the health of other patients since the bacteria in other patients will stick and bring more disease to other patients [26]. In addition, potion given to the patient is not sterile because it is processed in the same container with a container herb for other patients so that it is not sterile and will be the proliferation of bacteria that 
would endanger the patient [27]. Furthermore, traditional medicine has its limitations, the diagnosis of the patients are not always accurate because it is only seen from the outside [28]. Additionally, physician performs the treatment only feel the broken bones by touching, it is not detailed and precise, and this is not reccommended because somebody's feeling could be wrong [29]. This is because the physician does not have the tools to look inside the human body as a tool that is in the hospital [30].

\section{CONCLUSION}

There is the influence of knowledge and attitudes in traditional medicine to victims of traffic accidents.

\section{REFERENCE}

[1] Syahputra Tunggal, 2005. Franchising: Konsep dan Kasus, Jakarta, Harvarindo.

[2] Thomas C.Timmreck, PhD, 2005, Epidemiologi Suatu Pengantar (An Introduktion To Epidemiology) Edisi 2. Jakarta: Penerbit Buku Kedokteran, EGC.

[3] Ditjen Hubdat. 2014. Perhubungan Darat dalam Angka. Jakarta.

[4] Andriani, R., 2013. Gambaran Perilaku Penjual Peptisida di Desa Ujong Baroh Kecamatan Johan Pahlawan Kabupaten Aceh Barat. Universitas Teuku Umar: Meulaboh.

[5] Badan Intelijen Negara, 2014, Kecelakaan Lalu Lintas Menjadi Pembunuh Terbesar Ketiga. [Online, diakses tanggal 2 Januari 2014].

URL: http://www.bin.go.id/awas/detil/197/4/2/01/2014/kecelakaanlalu-lintas-menjadi-pembunuh-terbesar-ketiga.

[6] Asmino, P., 2002. Pengalaman Peribadi dengan Pengobatan Alternatif. Jakarta: Airlangga University Press.

[7] Cambron, J.A, Dexheimer, J., Coe, P., 2006.Changes in blood pressure after various forms of therapeutic massage: a preliminary study. J Altern Complement.

[8] Ayu. 2013. Hubungan Antara Faktor Pengemudi Dan Faktor Lingkungan Dengan Kepatuhan Mengendarai Sepeda Motor. Jurnal Berkala Epidemiologi, Vol. 1, No. 2 September 2013: 192-200.

[9] DINKES Nagan Raya. 2014. Surveilans Terpadu Penyakit Berbasis Puskesmas Sentinel. Nagan Raya.

[10] Furlan, A.D., Imamura, M., Dryde n, T., Irvin, E., 2008. Massage for low-back pain. Cochrane Database Syst Rev.;(4):CD001929.

[11] Gopalan SS, Mohanty S, Das A. 2012. Assessing community health workers' performance motivation: a mixed-methods approach on India's Accredited Social Health Activists (ASHA) programme. BMJ Open, 2(1557).

[12] Beider, S., Mahrer, N., Gold, J.,2007. Pediatric Massage Therapy: An Overview for Clinicians. Pediatric Clinics of North America.;54(6).

[13] Kholid, A., 2012. Promosi Kesehatan dengan Pendekatan Teori Perilaku, Media, dan Aplikasinya. Rajawali Pres: Jakarta.

[14] Damsar. 2009. Pengantar Sosiologi Ekonomi. Jakarta: Kencana Prenada Media.
[15] Kutner. 2008. Massage therapy versus simple touch to improve pain and mood in patients with advanced cancer: a randomized trial. Ann Intern Med.

[16] Mangan, Y. 2003. Cara Bijak Menaklukan Kanker. Agromedia Pustaka. Jakarta.

[17] Notoadmodjo. 2005. Promosi Kesehatan dan Ilmu Perilaku. Penerbit: Rineka Cipta. Jakarta.

[18] Pusita Sari. 2012. Perilaku pencarian pengobatan pada pasien patah tulang di RSUD Dr. Kariadi Semarang. Skripsi. Universitas Diponegoro. Semarang.

[19] Puskesmas Parom. 2014. Data Korban Kecelakaan di Wilayah Kerja Puskesmas Parom. Seunagan.

[20] Rahayu, M, dkk. 2013.Pemanfaatan Tanaman Obat Secara Tradisional Oleh Masyarakat Lokal Di Pulau Wawonii. Sulawesi Tenggara, Bidang Botani. Pusat Penelitian Biologi, LIPI Bogor.

[21] Salim. 2002.Perubahan Sosial; Sketsa Teori dan Refleksi Metodologi Kasus di. Indoneisa. Yogyakata: PT Tiara Wacana.

[22] Mursito, B., 2002. RamuanTradisionaluntuk Pengobatan Jantung. Jakarta: PT Penebar Swadaya.

[23] Notoatmodjo. 2012. Promosi Kesehatan dan Perilaku Kesehatan. Rineka Cipta: Jakarta.

[24] Sudarma. 2008. Sosiologi untuk Kesehatan. Jagakarsa: Salemba Medika.

[25] Venesy, D. A., 2007. Physical medicine and complementary approaches. Neurol Clin .;25(2):523-37.

[26] WHO. 2002. Traditional Medicine strategi 2002-2005. Diunduh 10 oktober 2010 dari http://whqlibdoc.who.int.

[27] Notoadmodjo, S., 2007. PromosiKesehatan\&IlmuPerilaku. 1st ed. Jakarta: Rineka Cipta.

[28] Yusherman. 2008. Epidemiologi Kecelakaan Lalu Lintas. Rineka Cipta, Bandung

[29] Zulhadi. 2013. Kecelakaan Lalu Lintas di Aceh. Ajnn. Net. Aceh.

[30] Nawawi. 2001.Metode Penelitian Sosial. Yogyakarta: Gadjah Mada 